\title{
$\nabla$ \\ A especificidade da informação arquivística
}

\author{
Heloísa Liberalli Bellotto \\ USP
}

Não se pode entender o mundo hoje sem que se compreenda o alcance, a importância e o peso da decantada globalização, tomada esta não no sentido menos restrito dos termos puramente econômicos e sim no da sua dimensão mais ampla: a do conhecimento mútuo, da comunicação, do intercâmbio, da transformação e da adaptação (quando necessárias), em prol de uma tentativa de cooperação e entendimento universais e em beneficio de uma qualidade de vida mais satisfatória e benéfica ao ser humano em todos os quadrantes da Terra.

Área das mais propícias para levar a cabo esta tarefa - a da comunicação e informação -, já que, por sua própria natureza, permeia todo o espaço do conhecimento - desde o saber até o fazer -, ela pode apostar, com segurança, em iniciativas como a deste Simpósio Internacional. A heterogeneidade de geografias, de zonas de atuação, de objetivos e de interesses profissionais de seus participantes - oradores e assistentes - não impedem, até pelo contrário, demonstram as potencialidades da globalização, no seu sentido mais nobre e promissor.

$\mathrm{Na}$ medida em que se intercambiem realidades e na medida em que se valorizem os pontos comuns, levando em conta as vantagens que deste fato se pode auferir, iremos compreendendo também que, para bem configurar a identificação e a cooperação, é preciso ir além da simples descoberta das justaposiçōes. É preciso, sobretudo, também termos noção exata da nossa diversidade. Embora possa parecer paradoxal, é no conhecer muito bem as diferenças entre a natureza, os meios e os objetivos das diferentes áreas - e respeitando-os - que os seus profissionais poderão lograr uma efetiva e proficua colaboração.

Este prólogo é para tentar introduzir a razão da minha 
presença neste Simpósio. Em princípio, ela é justificada para que se possa discutir a especificidade da informação arquivística. Isto é, basicamente a informação jurídico-administrativa ou a relativa ao funcionamento das organizações e entidades, diante das diferentes formas com que se apresenta a informação em geral, quer seja a jornalística (a da mídia em geral), quer seja a técnicocientifica, quer seja a sociocultural.

Quer consideremos a informação na sua acepção mais ampla como "tudo o que o receptor recolhe (ou se apercebe) antes que nele se verifique qualquer processo intelectual" (Desantes Guanter, 1987), quer consideremos mais especificamente como "conhecimento inscrito/gravado sob forma escrital impressal numérica, oral ou audiovisual" (Le Coadic, 1996), como "ação e efeito de comunicar dados" (Vega de Deza, 1996) ou como "coisa", como objeto, como prova.mais do que como processo ou conhecimento (Buckland, 1991). A informação pode ser vista ainda como "qualquer atribuição do pensamento humano sobre a natureza e a sociedade, desde que verbalizada ou registrada" (Lopes, 1996). Em qualquer uma destas abordagens apercebemo-nos de que a informação necessita de um veículo, de um suporte para ser transferida, para ser registrada e conhecida posteriormente à sua produção. A informação seria, portanto, uma substância, uma matéria que passa por um processo de comunicação para chegar a um receptor que dela faz uso e consumo.

Entretanto, na vastíssima área da informação/comunicação/ documentação definem-se campos específicos marcados pela diversidade da informação quanto à sua natureza, seus objetivos, sua origem, seus usos, seus veículos, seu armazenamento, sua disseminação e os seus públicos de interesse.

Dentre estes campos que são objeto de estudo das ciências da informação situa-se o das ciências documentárias, isto é, aquelas que se ocupam da informação registrada em suportes chamados documentos, quer sejam os da área administrativa e/ou da área jurídica. $\mathrm{O}$ que vai distinguir estes diferentes tipos de documentos e de informaçōes nele contidas, muito mais do que suportes, formas e formatos, vão ser justamente aqueles elementos acima mencionados: natureza, objetivos, usos etc..

Se os arquivos são conjuntos orgânicos de informações 
registradas em suportes tradicionais ou eletrônicos, cujos conteúdos são relativos à criação, ao funcionamento, à evoluçāo, às atividades, às transações, às transformações estruturais e funcionais, assim como às relações externas e internas de uma entidade pública ou privada, podendo ser ainda o conjunto das informaçōes relativas à vida civil e profissional das pessoas físicas, eles (ns arquivos) podem ser considerados como recursos probatórios e informativos. "A informação arquivistica faz parte dos recursos documentais que, ao lado dos recursos humanos, financeiros e materiais, toda organização utiliza para seu funcionamento" (Garon, 1984). Na verdade, para além da utilidade prática e cotidiana em termos do andamento da entidade e das provas jurídico-administrativas de sua existência e gestão, tratase da informação que ela acumulou e que pode demonstrar como atingiu os seus objetivos, confeccionou a sua imagem e integrou. se na sociedade na qual está inserida.

Este é o ponto básico da identificação da informação arquivística referentemente às informações de outra natureza: a de que ela é produzida dentro do contexto do exercício das funções/objetivos a que se propõem as entidades e neste sentido é que as informações são orgânicas: por guardarem entre si as mesmas relações que se formam entre as competências e atividades das entidades. Têm a ver, portanto, com a gestão administrativa e com o cumprimento das im posiçōes jurídicas. Entretanto, os conteúdos informacionais dos arquivos não são apenas concernentes à administração, isto é, ligados às atividades-meio de uma entidade; eles podem tam bém ser de conteúdo científico, técnico, filosófico, religioso, militar, artístico ou o que seja ainda, desde que não desgarrados do produtor/acumulador do arquivo (Lopes, 1996). A presença destes documentos nestes arquivos não $\dot{e}$, portanto, aleatória. É que aquelas áreas do conhecimento estarāo naturalmente relacionadas com as suas atividades-fim, isto é, aquelas que dão a forma e a razāo de ser de sua existência, justificando-lhe a presença em determinado contexto social.

O Comitê Internacional de Arquivos aponta para a informaçāo arquivística uma dupla função: a primeira, no interesse da eficácia administrativa ela será produzida, organizada, conservada, utilizada e, em parte, eliminada; a segunda, no interesse da pes- 
quisa, seja a relativa à evolução das organizações acumuladoras, seja a relativa à história do contexto social que a produziu e conservou (apud Ducharme \& Rousseau, 1980). No entanto é preciso não esquecer-se da terceira função: a que se liga aos interesses do cidadão. seus direitos e deveres para com as instituições civis ou para com o Estado. Para o cumprimento da primeira e da terceira funções há toda uma gestão dos documentos para que as informações sejam utilizadas tendo em vista razões funcionais, legais, jurídicas, administrativas etc. (inclusive amplia-se hoje, cada vez mais, o uso da informação orgânica como estratégia gerencial, no processo decisório, como têm reiterado os teóricos canadenses, Carol Couture à frente); para a segunda, em torno da pesquisa há todo um trabalho de conservação (que se traduz não apenas numa simples guarda mas sim em organização sistemática e numa manutenção física, seja dos arquivos tradicionais, seja dos virtuais), esta conservação aliada a todo um estudo e um preparo de acesso à informação que permita exploração ampla e profunda dos dados contidos nos documentos.

O exercício do direito à informação requer a existência de mecanismos que permitam o acesso e facilitem a consulta aos documentos. Tais mecanismos incluem o marco legal, a acertada organização do material, uma descrição de qualidade etc. (...) A tecnologia da informação, compreendida como avanços da computação e da telecomunicação, é hoje utilizada no armazenamento, organização, manejo, recuperação e intercâmbio da informação. Há toda uma responsabilidade profissional do arquivista de dar acesso à informação por meio de adequados instrumentos de pesquisa, inclusive relativamente aos arquivos virtuais.(Vega de Deza, 1996)

Há toda uma especificidade do arquivo comparativamente às coleções tradicionais de documentos, tais como as bibliotecas, os museus ou os centros de documentação. Na verdade, o arquivo "é um todo constituído por partes e é impossível entender e controlar o todo sem compreender e controlar suas partes, mesmo as maiselementares..." (Duranti, 1995). Para tanto é preciso partir da caracterização dos documentos de arquivo.

Quais são, afinal, objetivamente, as características marcantes capazes de identificar por si a informação/documento arquivístico 
das outras configuraçōes documentais? Os princípios básicos da arquivística são suficientes para demonstrar 0 quadro daquelas características: o da organicidade, o da proveniência, o da unicidade, o da indivisibilidade ou integridade, o da cumulatividade, 0 das três idades ou do ciclo vital dos documentos com o peso dos respectivos valores atribuídos a cada estágio deste ciclo. Expliquemo-los servindo-nos do Dicionário de Terminologia Arquivística (Camargo, Ana Maria \& Belloto, Heloísa Liberalli, 1996).

Organicidade é a "qualidade segundo a qual os arquivos refletem a estrutura, funções e atividades da entidade acumuladora em suas relações internas e externas". Proveniência é o princípio pelo qual os arquivos devem ser organizados, isto é, em obediência à competência e atividades da "instituição ou pessoa legitimamente responsável pela produção, acumulação ou guarda dos documentos, mantendo sua individualidade, não se devendo misturar documentos, enquanto produção/acumulação de origens diversas". Unicidade, a "qualidade pela qual os documentos de arquivo, a despeito de forma, espécie ou tipo, conservam caráter único em função de seu contexto de origem". Entende-se por "indivisibilidade ou integridade arquivística a característica derivada do princípio da proveniência segundo a qual um fundo de arquivo (isto é, o conjunto documental acumulado por determinada entidade) deve ser preservado sem dispersão, mutilação, alienação, destruição não autorizada ou acréscimo indevido". Outro princípio diferenciador dos arquivos é o da cumulatividade, isto é, o arquivo é uma formação "progressiva, natural e orgânica". A teoria das três idades é a sistematização das características dos arquivos correntes (arquivos ativos, com documentos em vigência, de uso administrativo); dos intermediários (arquivos semi-ativos que aguardam prazos de eliminação ou recolhimento aos arquivos históricos) e dos permanentes (arquivos inativos para administração mas de uso para pesquisa científica ou cultural). Nesta lógica compreendese facilmente o chamado ciclo vital dos documentos de arquivo, vale dizer, a "sucessão de fases por que passam os documentos, desde o momento em que são criados até a sua destinação final" (portanto, a eliminação ou guarda permanente).

Nesse quadro evolutivo da vida/utilização da informação 
arquivística tornam-se claros os chamados valores a ela atribuídos: o valor primário fica na primeira idade, obedecendo à demanda gerencial, o uso para o processo decisório, a dimensão jurídica e administrativa: o arquivo como prova (evidential value); já o valor secundário corresponde à ultrapassagem do primário. É 0 valor residual que valerá como testemunho, como informação freqüentemente de cunho muito mais amplo do que o restrito texto jurídico e administrativo do documento (informational value). (Jardim, 1996)

Deduz-se assim que a produção da informação arquivística na área dos órgãos públicos ou na área das organizações privadas é necessária, natural e espontânea, conseqüência da evolução institucional. Na sua acumulação não há a intencionalidade que há na constituição e desenvolvimento de uma coleção de documentos. Vê-se, portanto, em um documento de arquivo "uma expressão de memória coletiva; uma evidência de ato jurídico; um instrumento jurídico e administrativo, demonstrando uma função estática (cumpre dispositivos) e uma dinâmica (passa mensagens)". (Vega de Deza, 1996)

Há toda uma transcendência no documento de arquivo que está na sua base, que está fora dele, há toda uma anterioridade jurídica e administrativa que o prepara no tempo, assim como dele emana também uma projeção para o futuro - e esses são fenômenos que se situam muito além das palavras/signos de seu conteúdo. Um documento arquivístico é muito mais do que um suporte, um veículo e um conteúdo.

No caso do documento público, de caráter jurídico ou administrativo, há sempre a presença de um fato e de uma manifestação de vontade que dão origem ao ato escrito. Com a criação do documento pode-se criar, preservar, modificar ou concluir situações. Há todo um processo genético do documento sistemático e preestabelecido para que se legitime as ações nele implícitas. (Duranti, 1994)

Além disso, como outra grande característica arquivística, temos a de que estes documentos, com esta natureza e caráter, não têm sentido se tomados isoladamente. "Cada documento singular se considera em relação funcional com outros que formam parte do fluxo burocrático. de um determinado ato 
administrativo. Tem, portanto, que ver com os objetivos, as funcooes e a estrutura interna da entidade produtora.(Carucci, 1994)

A chegada da informática, já há algum tempo, a esse mundo da organização arquivística tão marcada por suas especificida. des, por sua vez dependentes dos regimes governamentais, das estruturas administrativas públicas e das normas legais assim como da organização interna e funcionamento das entidades privadas, tem-nos obrigado ainda mais a sermos precisos, metódicos e sistemáticos, buscando aliar as tecnologias aos princípios básicos que não devem ser menosprezados. Se abandonássemos as práticas baseadas em teorias já consagradas, estariamos, na verdade, cometendo um retrocesso em relação a espaços metodológicos e de harmonização universal duramente conquistados.

Problemas que a automação acarreta relativamente aos documentos dão-se, sobretudo, nos aspectos da autenticidade, do material do suporte e dos dados que são constantemente atualizados, substituindo dados anteriores (Delmas, 1993). Entretanto, soluções vêm sendo estudadas e adaptadas, chegando-se a níveis satisfatórios de interpretação das duas áreas.

Hoje já está claro para os arquivistas que, ao contrário de atitudes anteriores de resistência em que muitos se apegavam aos métodos tradicionais de classificação, armazenamento e descrição, já é possível admitir que não importa como o documento esteja armazenado, que esteja materialmente reunido ou mesmo que exista na forma física, palpável: o que importa é que a informação produzida possa ser recuperada e, o que é fundamental, sem ser isolada e sim sempre atrelada à estru tura, ao funcionamento e à organicidade da entidade produtora/acumuladora do arquivo.

Os profissionais da informação arquivística devem estar preparados para esta realidade hoje incontestável: a era dos documentos eletrônicos, seja como novos suportes, seja como meio de recuperação da informação sacada dos documentos em suporte tradicionais. Amplia-se o acesso à informação, ampliando-se também as questões éticas e as de preparação técnica especializada. Um reforço teórico na formação dos arquivistas, sobretudo quanto à diplomática moderna que lhes vai permitir 
bem saber discernir a natureza dos fatos, atos, ações. transações, pessoas, competências, procedimentos, processos e formas dos documentos arquivisticos, será, ainda que possa parecer paradoxal, muito útil para que saibam lidar com os documentos em suportes eletrônicos.(Duranti, c.1994)

As mudanças na mentalidade do arquivista são urgentes, pois, "diante da mudança de atitude em relação ao direito dos cidadãos à informação, da possibilidade de manipulação e da volatilidade dos documentos eletrônicos, da dependência dos sistemas em relação aos hardwares e aos softwares, do fracasso dos profissionais da tecnologia da informação em entender a natureza e a finalidade dos documentos de arquivo e, conseqüentemente, saber proteger a sua autenticidade, vem-se tornando necessário repensar a profissão.(Duranti, 1984)

Nesta compreensão, a de que, mais do que nunca, precisamos, na arquivística, de profissionais com sólida segurança a respeito de suas tarefas no que concerne à teoria, à metodologia, à prática e à aplicação da informática devidamente envolvida por aqueles pressupostos, reitero, para finalizar, o quadro da especificidade da informação arquivística:

Trata-se de conhecimento produzido no funcionamento das entidades públicas e privadas ou no decorrer da vida profissional das pessoas físicas que atuam como prova ou testemunho para fins jurídicos, administrativos ou de pesquisa do passado. Com isso, dentro dos seus limites de atuação, mas desenvolvendo a interdisciplinaridade e a cooperação entre áreas afins, acabaram todos, como já me referi no início da minha comunicação, por contribuir para um melhor entendimento social e por uma busca de excelência da qualidade de vida do cidadão - objetivos, aliás, almejados por todas as áreas e segmentos da sociedade.

\section{Bibliografia consultada}

BUCKLAND, M. Information as thing. Journal of American Society for Information Science, 42(5): 351-360, 1991.

CAMARGO, Ana Maria \& BELLOTTO, Heloísa Liberalli, coord. Dicionário de Terminologia Arquivística. São Paulo, AAB/Núcleo São Paulo, 1996. 
CURUCCI, Paola. II documento contemporaneo. Roma, La Nuova Italia Scientific, 1987.

Génesis del documento: redación, clasificación, original y copias. In: Documento y archivo de gestión. Carmona, Universidad Internacional Menendez Pelayo, 1994. p.61-78.

DELMAS, Bruno. Archival Science and Information Technologies. In: Menn-Haritz, Angelika, ed. Information Handling in Offices and Archives. Munchen, K. G. Saur, 1993. p.168-176.

DESANTES GUANTER, Jose Maria. Teoria y regimen jurídico de la documetación. Madrid, Eudema, 1987.

DUCHARME, Jacques \& ROUSSEAU, Jean-Yves. L'interdépendance des archives et de gestion des documents: une approche globale de l'archivistique. Montreal, Archives, 12(1):5·28, juin. 1980.

DURANTI, Luciana. Defining eletronic memory: the essential step in its preservation. (orig. datil. c. 1994)

Diplomatica: nuevos usos para una antica ciencia. Trad. De Manuel Vazquez. Córdoba, 1995.

Registros documentais contemporâneos. Rio de Janeiro, Estudos Históricos, 3: 50-64, 1994.

GARON, Robert. Ce que la technique ne remplace pas: l'information. Montreal, Archives, 15 (4): 5-12, mars 1984.

JARDIM, José Maria. A invenção da memória nos arquivos públicos. Braślia, Ciência da Informação, 25 (2): 209-216, maio-ago. 1996.

LE COADIC, Yves-François. A ciência da informação. Trad. De M. Y. De Filgueiras Gomes. Brasilia, Briquet de Lemos Livros, 1996.

LOPES, Luis Carlos. A informação e os arquivos. Niteró, Edufscar e Eduff, 1996.

ROBERGE, Michel. La gestion de l'information administrative. Montréal, Documentor, 1994.

SMIT, Johanna. Informação e documento. (Texto inédito, parte de futura publicação).

VEGA DE DEZA, Aurora de.la. Archivos e información. In: Nuestra palabra: textos archivisticos panamericanos. Lima, IPGH, Comisión de Archivos, 1996. 
